\title{
NAHIV İLMINDE AMEL ŞARTI OLARAK İHTISÂS (ÖZGÜLÜK) OLGUSU
}

\section{The Phenomenon of "IkHtisās"( Specifity) as an Effect Clause} IN NAHWW

\section{YUNUS İNANÇ}

Dr. Öğr. Üyesi, Karamanoğlu Mehmetbey Üniversitesi, İslami İlimler Fakültesi, Temel İslami Bilimler Bölümü Asst. Prof., Karamanoğlu Mehmetbey University, Faculty of Islamic Sciences, Department of Basic Islamic Sciences

\author{
yunus.inanc@gmail.com \\ orcid.org/0000-0003-3659-1634
}

\begin{tabular}{rl}
\hline MAKALE BiLGisi & ARTICLE INFORMATION \\
\hline Makale Türü & Article Type \\
Araştırma Makalesi & Research Article \\
Geliş Tarihi & Date Received \\
18 Kasım 2018 & 18 November 2018 \\
Kabul Tarihi & Date Accepted \\
15 Nisan 2019 & 15 Nisan 2019 \\
Yayın Tarihi & Date Published \\
Haziran 2019 & June 2019 \\
Yayın Sezonu & Pub Date Season \\
Haziran & June \\
DOI \\
https://doi.org/10.14395/ hititilahiyat.484742 \\
\hline
\end{tabular}

\section{Atif/Cite as}

İnanç, Yunus. "Nahiv İlminde Amel Şartı Olarak İhtisâs (Özgülük) Olgusu”. Hitit Üniversitesi İlahiyat Fakültesi Dergisi- Journal of Divinity Faculty of Hitit University 18/35 (Haziran/June 2019): 187-206.

https://doi.org/10.14395/ hititilahiyat.484742

İntihal/Plagiarism

Bu makale, en az iki hakem tarafından incelendi ve intihal içermediği teyit edildi. This article has been reviewed by at least two referees and scanned via plagiarism software.

http://dergipark.gov.tr/hititilahiyat

Copyright @ P Published by Hitit Üniversitesi, İlahiyat Fakültesi - Journal of Divinity Faculty of Hitit University, Çorum, Turkey. 


\section{Nahiv İlminde Amel Şartı Olarak İhtisâs (Özgülük) Olgusu The Phenomenon of "Ikhtisās"( Specificity) as an Effect Clause in Nạ̣w}

\section{Abstract}

The "āmil" attained by searching for the cause of the changes in the sentence is considered to be one of the most basic concepts in nahw. It has thoroughly shaped the frame of naḥw (Arabic Grammar). The concept of 'āmil has been referred in nậw's many controversial points. The main theme of the numerous nahw works has based on the 'āmil. It has been strived to solve many problems in nahw starting from this concept. However, the linguists during both the classical and modern periods have frequently criticized the concept of 'āmil and nahw shaped by it. On the other hand, there is another concept called "ikhtisās", which is dealt with the concept of "āmil" in the naḥw works. The specificity phenomenon (ikhtisās) here is that for an element to be active on other elements, that element is specific to the word group to which it is linked. The specificity phenomenon (ikhtisās) regarded as a prerequisite for being 'āmil has been mentioned during controversial topics of nahw and thus changed the direction of the discussion. In this study, firstly the basic issues related to the 'āmil are to be touched on and then it is to be focused on the specificity phenomenon seen as the basic condition of being 'āmil and discussed in nahw works in this context. The examples of language rules in which the concept of specificity is determinative and that situated in nahw works are to be examined. There is an important principle among the principles that Arabic Linguists have largely allied with, and since it is directly related to the topic of our study it is seen necessary to lay stress on it as well. This is the principle that the 'âmils of the nouns and verbs are unique, and there is no effect of the 'âmils of the nouns on verbs and the 'āmils of the verbs on the nouns.

Key Words: Arabic, Naḥw (Arabic Grammar), Usūl al-Nahw, 'Āmil, Ikhtisās.

\section{Summary}

Concept of "āmil" that reached as a result of the search for the cause of the changes in the sentence has seen as one of the most basic concepts of Nahw and has shaped the whole frame of the Nahw. The concept of 'āmil was discussed at Nahw's many controversial points. The main theme of most of the Nahw works was based on the 'àmil. Many problems in Nahw has been solved by acting from the concept of 'àmil. On the other hand another concept which is dealt with in the Nahw works with the concept of "āmil" was the concept of "ihtisās". The specificity phenomenon (ihtisās) that seen as a prerequisite for a word to be 'āmil has been voiced in controversial topics in the Nahw and changed the direction of the discussion. As it is known, in Arabic a word is classified into three; as noun, verb and letter. The meaningful structure formed by words is called sentence or phrase. The fact that the words in the sentences become different from their previous form (before getting included in the sentence) has been examined greatly by the linguist scientists and the reasons of the change have been discussed in detail. The linguists have scrutinized the changing element in the sentence, the factor causing it and the change itself within this context. The linguists seeing that the changes detected are different from one another have thought the factors causing the change might be different as well and thus they have searched on the related field in detail. As a result of the linguists' studies on the uses in language the changes of elements in the sentence and the factors causing 
the changes have gained a conceptual frame. The elements in the sentence have got distinctive names according to their functions. Pursuant thereto, the factors causing the change have been called as "āmil", the changed element as "ma'mūl" and the change itself as "amel".

The 'āmil phenomenon found out as a result of the Arabic Linguists' attempts to explain the changes in a sentence, has determined the theme, frame and topics of the Works written in Arabic syntax (Nahw Works). As the 'āmil phenomenon has been so strong that the attempt to explain the reasons for the changes in the language has placed on an equivalent level with the binding in the cause-and-effect relationship for the concrete events. Likewise, the causality relationship that every event occurred needs a reason has been valid for the usages in the language and it has been specified that every "amel" would need an "āmil". Because of the fact that it is not possible to discuss the Arabic syntax rules without referring to the concept 'āmil which is applied by the Arabic Linguists to explain the changes in the sentence, it has become one of the fundamental concepts of Arabic Grammar. Looking at the literature they have made during the process, it might be said, the Arabic Linguists have considerably agreed on the concept 'āmil. However, examining in detail, it must be stated that there are also the points they disagree besides the basic issues they agree on.

There is an important principle among the principles that Arabic Linguists have largely allied with, and since it is directly related to the topic of our study it is seen necessary to lay stress on it as well. This is the principle that the 'âmils of the nouns and verbs are unique, and there is no effect of the 'àmils of the nouns on verbs and the 'āmils of the verbs on the nouns. In this regard, focusing on what the Arabic Linguists decree as an 'āmil, on what grounds they estimate a word as an 'āmil, a word which is an 'āmil according to some and not an 'āmil according to some others etc., some concepts frequently emphasized in the Nahw works have been encountered. The first of these concepts is ikhtisās (ownership). Ikhtisās has been the concept which the Arabic Linguists have expressed at the beginning of the discussions on whether a word is an 'āmil or not and it has a role to make changes on the other words or not. In other words a word's being an 'àmil has been conditioned to whether it has features of ikhtisās. It has been seen that this phenomenon (ikhtisās) has been under most of the controversial issues in the Nahw Works. The interpretations and explanations of the linguists who lay ikhtisās down as a condition for 'āmil have been different from the ones of the linguists who do not require ikhtisās as a condition. In this study, firstly the place of ikhtisās concept in the general framework is discussed and then its reflections in nahw rules are presented. Furthermore, one of the concepts related to the same concept and sometimes used together is the similarity phenomenon. In this study, ikhtisās (ownership) phenomenon is focused on initially, and if it is seen necessary the similarity phenomenon will be referred too.

\section{Öz}

Cümledeki değişikliklere yol açan neden arayışının sonucunda ulaşılan 'âmil olgusu, nahiv ilminin en temel kavramlarından sayılmış, nahvin bütün çerçevesini şekillendirmiştir. 'Âmil olgusu nahivdeki pek çok tartışmalı noktada gündeme gelmiştir. Nahiv eserlerinin büyük bir kısmının ana teması 'âmil merkezli olarak şekillenmiş ve bu eserlerin teorik çerçevesi 'âmil nazariyesi üzerine oturmuştur. Nahivdeki birçok meseleye 'âmil kavramından hareketle çözüm bulunmaya çalışılmıştır. Ancak gerek klasik dönem dilcileri ve gerekse modern dönem dilcileri 
'âmil kavramını ve buna bağlı olarak şekillenen nahvi çokça eleştirmişlerdir. Öte yandan nahiv eserlerinde 'âmil kavramı ile irtibatlı olarak ele alınan bir diğer kavram da "ihtisâs" kavramı olmuştur. Burada ihtisâstan kastedilen, bir ögenin başka ögeler üzerinde etkin olması için sadece o ögenin bağlı olduğu kelime gurubuna özgü olmasıdır. Bir ögenin 'âmil olması için ön şart niteliğinde görülen ihtisâs olgusu nahivdeki tartışmalı konularda dile getirilmiş ve tartışmanın yönünü değiştirmiştir. Bu bakımdan bu çalışmada öncelikle 'âmil ile ilgili temel hususlara temas edilecek, ardından 'âmil olmanın temel şartı olarak görülen ve nahiv eserlerinde bu bağlamda ele alınan ihtisâs olgusu üzerinde durulacaktır. Nahiv eserlerinde yer alan ve ihtisâs olgusunun belirleyici olduğu dil kurallarının örnekleri irdelenecektir. Nahivcilerin büyük oranda ittifak ettiği ilkeler arasında önemli bir ilke vardır ki çalışmamızın konusu ile doğrudan irtibatlı olduğundan burada ayrıca ele alınacaktır. Bu da isim ve fiillerin 'âmillerinin kendilerine özgü olduğu, isimlerin 'âmillerinin fiiller üzerinde, fiillerin 'âmillerinin de isimler üzerinde amel etmeyeceği ilkesidir.

Anahtar Kelimeler: Arapça, Nahiv, Nahiv Usûlü, 'Âmil, İhtisâs.

\section{GíRİs}

Bilindiği üzere Arapçada kelime; isim, fiil ve harf olmak üzere üç türlüdür. Kelimelerin oluşturduğu anlamlı yapıya cümle veya terkip denmektedir. Cümle içinde yer alan kelimelerin terkibe dâhil olmadan önceki durumundan farklı bir hale dönüşmesi dilciler tarafından çokça üzerinde durulan bir konu olmuş, söz konusu değişimin nedenleri detaylıca sorgulanmıştır. Bu çerçevede dilciler cümledeki değişen unsuru (ma'mûl), değişime neden olan etkeni ('âmil) ve ortaya çıkan değişikliği ('amel) etraflıca irdelemişlerdir. Tespit edilen değişikliklerin farklılık arz ettiğini gören dilciler değişime neden olan etkenlerin de farklı olabileceğini düşünerek ilgili

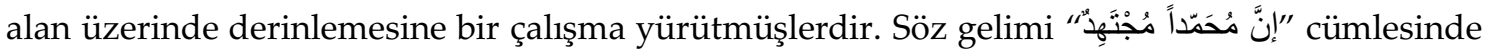
yer alan " kelimelerinin kendileri için mümkün olan diğer şekillerden biri üzere gelmeyip cümlede geçtiği şekilde gelmesi açıklanma gereği duyulmuş ve dilciler istikra yoluyla tespit ettikleri örneklerden yola çıkarak inne (إنّ) harfinin geçtiği cümlelerde benzer değişimlerin olduğunu fark etmişler ve buradan hareketle genel hükümlere ulaşmışlardır. Bu

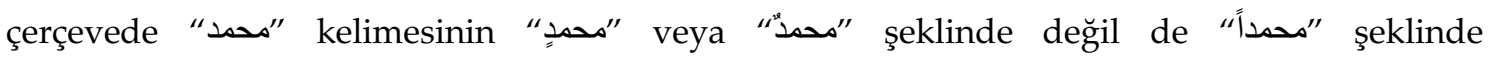

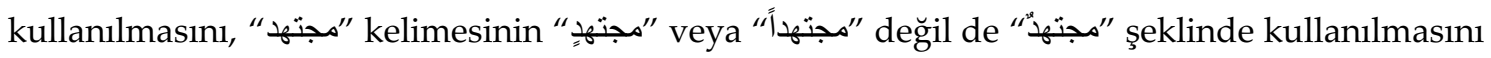
cümlenin başında yer alan "inne" ile irtibatlandırmışlardır. Dolayısıyla dilcilerin bu ve benzeri kullanımlar üzerinde yaptıkları çalışmalar sonucunda cümlede yer alan unsurların geçirdikleri değişimler ve değişime neden olan etkenler belli bir kavramsal çerçeve kazanmıştır. Buna göre söz konusu değişime sebep olan etkenlere 'âmil, değişen unsura ma'mûl ve ortaya çıkan değişikliğe ise amel denmiştir.

Nahivcilerin cümlede yer alan değişiklikleri açıklama girişimleri sonucunda ulaştıkları 'âmil olgusu nahiv eserlerinin temasını, çerçevesini ve konuların ele alınış üslubunu belirlemiştir. Zira 'âmil olgusu o kadar güçlü bir olgu olmuş ki dildeki değişimlerin sebeplerini izah çabası somut olaylar için geçerli olan neden sonuç ilişkisindeki bağlayıcılıkla eşdeğer bir düzleme yerleşmiştir. Meydana gelen her olayın (hades) bir "muhdis"e ihtiyaç duyduğu şeklindeki nedensellik ilişkisi, dildeki kullanımlar için de geçerli görülmüş ve her "'amel" in bir 
“'âmil"e ihtiyaç duyacağı belirtilmiştir. ${ }^{1}$ Nahivcilerin cümlede meydana gelen değişiklikleri açılamak üzere başvurdukları bir kavram olan 'âmil kavramından söz etmeksizin nahiv kurallarını ele almak mümkün olmadığından 'âmil kavramı Arap gramerinin en temel kavramlarından birisi olmuştur.

Nahivcilerin süreç içinde oluşturdukları literatüre bakarak 'âmil kavramı üzerinde büyük oranda ittifak ettikleri hususların olduğunu söyleyebiliriz. Ancak detaya inildiğinde ittifak ettikleri temel hususların yanında ihtilaf ettikleri konuların olduğu da söylenmelidir. Nahivcilerin genel olarak ittifak ettikleri hususlara gelince söz gelimi iki 'âmilin bir ma'mûl üzerinde aynı anda etkide bulunamayacağ $1^{2}$, 'âmillerin en güçlüsünün fiil olduğu, isim ve harflerin fiile benzerliği oranında 'âmil olmaya yaklaştığ ${ }^{3}$, 'âmillerin lafzî ve manevî olmak üzere ikiye ayrıldığı ve lafzî 'âmilin manevî 'âmilden daha kuvvetli olduğu', 'âmillerin aslî ve fer'î olmak üzere ikiye ayrıldığı ve fer'î 'âmilin aslî 'âmildeki özelliklerin tamamına sahip olmadığından aslî 'âmilden zayıf olduğứ, 'âmil ile ma'mûlünün arasının ayrılmamasının asıl olduğ $u^{6}$, harflerin ma'mûl olamayacağ ${ }^{7}$, isimlerde amel etmemenin asıl olduğ $\mathbf{u}^{8}$ ve isimlerin ‘âmillerinin fiillerin ‘âmillerinden güçlü olduğ $\mathrm{u}^{9}$ gibi hususlar bunların başında gelmektedir.

Nahivcilerin büyük oranda ittifak ettiği bu ilkelerin yanında önemli bir ilke daha vardır ki çalışmamızın konusu ile doğrudan irtibatlı olduğundan ayrıca zikretmek gerekli görülmüştür. Bu da isim ve fiillerin 'âmillerinin kendilerine özgü olduğu, isimlerin ‘âmillerinin

\footnotetext{
${ }^{1}$ Ebû Bişr 'Amr b. 'Osman b. Kanber Sîbeveyh, el-Kitâb, nşr. Abdüsselâm Muhammed Hârun (Kahire: Mektebetu'lHancî, 1988), 1: 13; Ebu'l-Berekât Abdurrahman İbnü'l-Enbârî, el-İnsâf fì mesâili'l-hnlâf beyne'l-basriyyîn ve'l-kûfiyyîn (Beyrut: Mektebetu'l-asriyye, 2007), 1: 66, 67; Halid b. Abdullah Ezherî, Şerhu't-Tasrîh ale't-Tavzîh, nşr. Muhammed Bâsıl 'Uyûnu's-Sûd (Beyrut: Dâru'l-kütübi'l-ilmiyye, 2000), 1: 56; İbrahim Mustafa, İhyâu'n-nahv (Kahire: Matbaatu lecneti'ttelif ve'n-neşr, 1992), 31 vd.; Mustafa İbn Hamza, Nazariyyetu'l-'âmil fi'n-nahvi'l-Arabî-Dirâse te'sîliyye ve terkîbiyye (B.y.: y.y., 2004), 231 vd.; Halil Ahmed 'Amâyire, el-'Âmilu'n-nahvî beyne mueyyidîhi ve muarizîhi ve devruhu fí tahlîli'l-lugavî (B.y.: y.y., 1985), 59, 60.

2 Ebû Bekr Muhammed b. Sehl İbn Serrâc, el-Usûl fi'n-nahv, nşr. Abdülhüseyin el-Fetlî (Beyrut: Müessesetu'r-risâle, 1996), 1: 90; Ebu'l-İrfan Muhammed b. Ali Sabbân, Hâşiyetu's-Sabbân 'alâ Şerhi'l-Üşmûnî 'alâ Elfiyyeti'bni Mâlik E Şerhu'şşevâhid li'l'Aynî, nşr. Tahâ Abdurraûf Sa'd (Yyy: el-Mektebetu't-Tevfîkıyye, ts.), 1: 308.

3 Ebu'l-Hasan Muhammed b. Abdullah Verrâk, 'Ilelu'n-nahv, nşr. Mahmud Câsim Muhammed Dervîş (Riyâd: Mektebetu'r-rüşd, 1999), 196, 442; İbnü'l-Enbârî, el-İnsâf, 1: 68; Ebu'l-Bekâ Muhibbuddîn Abdullah b. Hüseyin “Ukberî, el-Lübâb fì ıleli'l-binâi ve'l-i'rab, nşr. Gâzî Muhtâr Tuleymât - Abdülilâh Nebhân (Beyrut-Dımaşk: Dâru'l-fikr el-muâsırDâru'l-fikr, 1995), 1: 209; Cemâlüddîn Ebû Abdullah Muhammed b. Abdullah İbn Mâlik, Şerhu't-teshîl li İbn Mâlik, nşr. Abdurrahman Seyyid - Muhammed Bedevî el-Mahtûn (Kahire: Hicr li't-tıbâa ve'neşr, 1990), 1: 313; Ebû Hayyân Endelûsî, et-Tezyîl ve't-tekmîl fì şerhi Kitâbi't-Teshîl, nşr. Hasan Hindâvî (Riyâd: Daru Künûzi İşbiliyâ, 2013), 3: 259; Celâlüddîn Süyûtî, Hem'u'l-hevâmi' fì şerhi cem'i'l-cevâmi', nşr. Ahmed Şemsüddîn (Beyrut: Dâru'l-kütübi'l-ilmiyye, 1998), 1: 311, 490.

4 İbnü'l-Enbârî, el-İnsâf, 1: 39; Ebu'l-Kâsım Abdurrahman b. Abdullah Süheylî, Netâicu'l-fiker fi'n-nahv, nşr. Adil Ahmed Abdulmevcud, Ali Muhammed Muavvad (Beyrut: Dâru'l-kütübi'l-ilmiyye, 1992), 62, 312; İbn Mâlik, Şerhu't-teshîl li İbn Mâlik, 1: 313; Endelûsî, et-Tezyîl ve't-tekmîl, 3: 260; 4: 54, 183; 11: 243; Ezherî, Şerhu't-Tasrîh ale't-Tavzîh, 1: 370; Süyûtî, Hem'u'l-hevâmi', 1: 490; Sabbân, Hâş̧iyetu's-Sabbân, 1: 357; 2:38.

${ }^{5}$ İbn Hamza, Nazariyyetu'l-'âmil, 291.

6 Sîbeveyh, el-Kitâb, 2: 281; Ebu'l-Hasan Muhammed b. Yezîd Müberred, el-Muktedab, nşr. Muhammed Abdulhâlik Udayme (Kahire, 1994), 2: 30; 4: 156, 376; İ̉n Serrâc, el-Usûl fi'n-nahv, 1: 128; 2: 237; “Ukberî, el-Lübâb, 1: 155; Endelûsî, et-Tezyîl ve't-tekmîl, 4: 246; Ezherî, Şerhu't-Tasrîh ale't-Tavzîh, 1: 487; Süyûtî, Hem'u'l-hevâmi', 1: 375; 3: 94; İbn Hamza, Nazariyyetu'l-âmil, 305.

7 İbn Hamza, Nazariyyetu'l-'âmil, 266.

8 Verrâk, 'Ilelu'n-nahv, 240; “Ukberî, el-Lübâb, 1: 437; Endelûsî, et-Tezŷ̂l ve't-tekmîl, 11: 80; Süyûtî, Hem'u'l-hevâmi', 3: 48; İbn Hamza, Nazariyyetu'l-'âmil, 284.

${ }^{9}$ Sîbeveyh, el-Kitâb, 1: 405; Ebu'l-Feth Osman İbn Cinnî, Sirr'u sınâti'l-i'râb, nşr. Hasan Hindâvî (Dımaşk: Dâru'l-kalem, 1993), 1: 345; 2: 681; Ebu'l-Feth Osman İ̉n Cinnî, el-Hasâis, nşr. Muhammed Ali Neccâr (Kahire: Mektebetu'l-ilmiyye, 1952), 2: 388; Ebu'l-Bekâ Ya'îş b. Ali İbn Ya'îş, Şerhu'l-Mufassal li'z-Zemahşerî, nşr. Emîl Bedi' Yakub (Beyrut: Dâru'lkütübi'l-ilmiyye, 2001), 4: 294; 5: 145; Süyûtî, Hem'u'l-hevâmi', 2: 288.
} 
fiiller üzerinde, fiillerin 'âmillerinin de isimler üzerinde amel etmeyeceği ilkesidir.10 Nitekim İbnu'l-Enbârî (ö. 577/1181) bir edat hakkında isimlerin 'âmili olduğu hükmü verildikten sonra o edatın fiillerde 'âmil olmasının mümkün olamayacağını söylemiştir.11

Nahivcilerin 'âmil ile ilgili sıklıkla vurguladıkları hususları bu şekilde belirttikten sonra 'âmil konusunun çalışmamızı ilgilendiren yönüne dönebiliriz. Bu bağlamda nahivcilerin neye 'âmil hükmünü verdikleri, bir kelime hakkında neye dayanarak 'âmil dedikleri, bir kısmına göre 'âmil olan bir kelimenin diğerlerine göre 'âmil sayılmaması gibi meseleler üzerinde durulduğunda nahiv eserlerinde sıklıkla vurgulanan bazı kavramlarla karşı karşıya kalınmıştır. Bu kavramların ilki ihtisâs (özgülük) kavramıdır. Yine aynı kavramla ilgili olan ve kimi zaman birlikte kullanılan kavramlardan biri de benzerlik (şebeh) olgusudur. Bu çalışmada başta özgülük olgusu üzerinde durulacak ve gerek görüldügünde benzerlik olgusuna da temas edilecektir.

\section{1. İHTISÂS OLGUSU}

İhtisâs kelimesi “خص" kökünden gelen "ختصن" fiilinin mastarıdır. Bir şeye bağlı kalma, bir şeye özgü olma, herhangi bir şeye değil de özellikle belirli bir şeye ilişme anlamlarına gelir. ${ }^{12}$ Nahivcilerin bir kelimenin 'âmil olup olmaması, cümledeki diğer kelimeler üzerinde değişiklik yapma yetkisinin bulunup bulunmaması tartışmalarında en başta dile getirdikleri kavram ihtisâs kavramı olmuştur. Bir başka ifadeyle bir kelimenin 'âmil olması ihtisâs şartını taşıyıp taşımamasına bağlanmıştır. Nahiv eserlerindeki tartışmalı meselelerin birçoğunun altında söz konusu olgunun yattığı görülmüştür. 'Âmillik için ihtisâsı şart koşan dilcilerin dile dair durumları ve dil kurallarını açıklama biçimleri ihtisâs şartını aramayan dilcilerin yorum ve açılama biçimlerinden farklı olmuştur. Burada öncelikle ihtisâs kavramının genel kabuldeki yeri ele alınacak, ardından nahiv kurallarındaki yansımalarına yer verilecektir.

Arapçadaki kelime türleri 'âmil olmak bakımından irdelendiğinde fiil, 'âmillerin en güçlüsü kabul edilmiş ve isimlerin asıl itibariyle 'âmil olmayacağı belirtilmiştir. Amel etmek fiillerde aslî, isim ve harflerde ise fer'î bir durum olarak görülmüştür. Çünkü fiiller doğrudan amel ederken isimlerin sadece fiile benzeyenleri amel etmektedir. Dolayısıyla amel etmek asıl itibariyle fiillere özgü iken isim ve harflerden 'âmil olanları için ayrı bir neden aranmıştır. Nahivcilere göre isim ve harflerin amel etmesini mümkün kılan bunların da bir şeye özgü olma konusunda fiillere benzemesidir. Görüldüğü üzere harflerin 'âmilliği ihtisâs olgusu çerçevesinde incelenmiştir. ${ }^{13} \mathrm{Bu}$ çerçevede harfler; isme özgü olup sadece isimlerin önüne gelen, fiile özgü olup sadece fiillerin önüne gelen ve isim ve fiil arasında müşterek olup hem isimlerin

10 Müberred, el-Muktedab, 2: 5, 7, 345; 3: 263; Hasan b. Abdullah b. Merzübânî Ebû Saîd Sîrâfî, Şerh'u Kitâb'i Sîbeveyh, nşr. Ali Seyyid Ali - Ahmed Hasan Mehdelî (Beyrut: Dâru'l-kütübi'l-ilmiyye, 2008), 1: 322, 323; 2: 53; Verrâk, 'Ilelu'n-nahv, 195, 240, 447; Endelûsî, et-Tezyîl ve't-tekmîl, 11: 188; İbn Cinnî, el-Hasâis, 1: 204; İbn Ya'îş, Şerhu'l-Mufassal, 1: 268; 3: 45; 4: 294, 486; İbn Mâlik, Şerhu't-teshîl li İbn Mâlik, 4: 49; Celâlüddîn Süyûtî, el-İktirâh fì usûli'n-nahv, nşr. Abdulhakîm Atıyye (Dımaşk: Dâru'l-Beyrûtî, 2006), 153; Hem'u'l-hevâmi', 2: 300.

11 İbnü'l-Enbârî, el-İnsâf, 2: 471.

12 Ebu'l-Fadl Cemâlüddîn Muhammed b. Mukerrem İbn Manzûr, Lisânu'l-Arab (Beyrut: Dâru sâdir, 1414), 7: 24; Muhammed b. Ali Tehânevî, Mevsûatu keşşâf-ı ıstılâhâti'l-fünûn ve'l-'ulûm, nşr. Ali Dahrûc (Beyrut: Mektebetü Lübnan Nâşirûn, 1996), 1: 115; Ebu'l-Beka Eyyüb bin Musa el-Kefevî, el-Külliyyât mu'cem fi'l-mustalahât ve'l-furûki'l-lugaviyye, nşr. Adnan Derviş, Muhammed el-Mısrî (Beyrut: Müessesetu'r-risâle, 1998), 193; Rağıb İsfahanî, Müfredât'u elfâzi'l-Kur'ân, nşr. Safvân Adnân Dâvûdî (Dımaşk \& Beyrut: Dâru'l-kalem \& Dâru'ş-Şâmiye, 2009), 284.

${ }_{13}$ Muhammed b. Yusuf b. Ahmed Nâzıru'l-Ceyş, Temhîdu'l-kavâld bi şerhi Teshîli'l-fevâid, nşr. Ali Ahmed Fahir ve diğerleri (Kahire: Daru's-selam, 2007), 3: 1302, 1303.

|192|

Hitit Üniversitesi İlahiyat Fakültesi Dergisi, 2019/1, Cilt: 18, Sayı: 35 
hem de fiillerin önüne gelebilen harfler olmak üzere üç kısma ayrılmıştır. ${ }^{14}$ Buna bağlı olarak dil ekolleri arasında farklı görüşlerin bulunduğunu ${ }^{15}$ hatırda tutmak kaydıyla 'âmillerle ilgili genel olarak kabul edilen en temel ilke şudur: İsim veya fiilden birine özgü olma durumuna göre üç guruba ayrilan harflerden sadece isme veya sadece fiile özgü olanlar 'âmil olabilirken hem ismin ve hem de fiilin önüne gelebilen harfler 'âmil olamaz. 'Âmil sadece amel ettiği şeye özgü olmak zorundadır. ${ }^{16}$

Görüldüğü üzere özellikle harflerin 'âmil kabul edilmesi ve amel edebilmesinin öncelikli şartı, isim veya fiil gurubundan sadece birine özgü olmasıdır. Bu şartın yerine getirilmesi halinde 'âmil sayılması asıl olandır. Her harfin neye özgü ise onda amel etmesi, birine özgü değilse amel etmemesi kıyâsın gereğidir. Bu nedenle bir alana özgü olma şartını taşımayan bir ögenin 'âmil sayıldığına dair kullanımlarla karşılaşıldığında 'âmil olmasını gerektirecek başka nedenler aranmıştır. ${ }^{17}$ Nahiv eserlerinde konuların ele alınması esnasında bu durum sıklıkla dikkate alınmış ve söz konusu şart, tartışmalı durumlarda hep dile getirilmiştir. ${ }^{18}$ Ayrıca kaynaklarda yer alan tartışmalar incelendiğinde sözünü ettiğimiz olgunun nahivciler nezdinde temel ve bilinen bir kural olduğu görülmüştür. ${ }^{19}$ Diğer yandan bazı nahivciler, söz konusu kavram yerine yine aynı çerçevede "istibdâd" kavramına yer vermişlerdir. Bir ögenin başka bir ögede 'âmil olması için bir türe bağlı kalması, ayrılmamak üzere ona ilişmesi anlamında kullanılan "istibdâd" kavramı da ihtisâs kavramı gibi kıyâsın gereğine işaret eden bir kavram olmuştur. ${ }^{20}$

\section{2. İHTISÂS OLGUSUNUN KULLANIMLARI}

Daha önce de ifade edildiği üzere 'âmil kavramı Arap dil kurallarının genel çerçevesine güçlü bir şekilde hâkim olan etkin bir unsur olmuştur. Nahiv eserlerinin teması 'âmil olgusu

14 Ebû Muhammed Abdullah Cemâlüddîn İbn Hişâm, Evdahu'l-mesâlik ilâ Elfiyyeti İbn Mâlik, nşr. Muhammed Muyhiddîn Abdülhamid (Beyrut: Mektebetu'l-asriyye, ts.), 1: 25, 26; Süyûtî, Hem'u'l-hevâmi', 1: 39, 40; Sabbân, Hâş̧iyetu's-Sabbân, 1: 89-92.

${ }^{15}$ Basralı dilcilere göre bir edatın âmil olması için isim veya fiilden birine has olması lazımdır. Sadece fiillere özgü olan fiillerde amel edebilirken harfi cerler gibi sadece isimlere özgü olanlar da sadece isimlerde amel edebilir. İsim veya fiilden herhangi birine özgü olmayıp her ikisi ile de kullanılanları ise âmil değildir. Kûfeli dilcilere göre durum böyle değildir. Lâm-1 ta’lil isim veya fiilden herhangi birine has olmadığı halde nasp etmektedir. Bk. İbrahim Sâmerrâî, en-Nahvu'l-Arabî fí muvâceheti'l-asr (Beyrut: Dâru'l-cîl, 1995), 91 vd.

16 İbn Ya'îş, Şerhu'l-Mufassal, 1: 440; Ebû Muhammed Abdullāh b. Ahmed b. Ahmed b. Ahmed İbnü'l-Haşşâb, elMürtecel fî̀ şerhi'l-Cümel, nşr. Ali Haydar (Dımaşk, 1972), 234.

17 İbnü'l-Haşşâb, el-Mürtecel fî̀ şerhi'l-Cümel, 175-177; İbn Mâlik, Şerhu't-teshîl li İbn Mâlik, 1: 313; Nâzıru'l-Ceyş, Temhîdu'l-kavâld, 2: 996; Endelûsî, et-Tezyîl ve't-tekmîl, 11: 114.

18 “Ukberî, el-Lübâb, 1: 126, 208, 365; 2: 30; İbn Ya'îş, Şerhu'l-Mufassal, 2: 47, 75; 4: 219, 224, 528; 5: 86, 144; İbn Mâlik, Şerhu't-teshîl li İbn Mâlik, 4: 12; Şerhu'l-kâfiyeti'ş-şâfiye, nşr. Abdülmünım Ahmed Hüreydî (Riyâd: Dâru'l-me'mûn li'tturâs, 1982), 1: 479, 480; 3: 1529; Endelûsî, et-Tezyîl ve't-tekmîl, 5: 277, 281; Ebû Muhammed Abdullah Cemâlüddîn İbn Hişâm, Muğni'l-lebîb an kutubi'l-eârib, nşr. Abdüllatif Muhammed el-Hatîb (Kuveyt: Silsiletu't-turâsiyye, 2000), 1: 212; Muğni'l-lebîb, 1: 212; Ebû Abdillâh Bedrüddîn Muhammed b. Muhammed b. Abdillâh b. Mâlik İbnü'n-Nâzım, Şerhu İbn Nâzım alâ Elfiyeti İbn Mâlik, nşr. Muhammed Bâsil 'Uyûn es-Sûd (Beyrut: Dâru'l-kütübi'l-ilmiyye, 2000), 214, 255; Ebû Abdillâh Şemsüddîn Muhammed b. Ebî Bekr b. Eyyûb İbn Kayyim İbn Kayyim el-Cevziyye, İrşâdü's-sâlik ilâ halli Elfiyeti İbn Mâlik, nşr. Muhammed b. Ivad b. Muhammed es-Sehlî (Riyâd: Mektebetu edvâi's-selef, 2002), 249, 253; Nâzıru'1Ceyş, Temhîdu'l-kavâld, 3: 1361, 1385; 8: 4149; Ebû İshâk İbrahim b. Mûsa Şâtıbî, el-Mekâsıdü'ş-şâfiye fí şerhı'l-hulâsati'lKâfiye, nşr. Ayyâd b. Îd es-Sübeytî (Mekke: Câmiatu Ummu'l-kurâ, 2007), 2: 10, 344; 6: 96; Süyûtî, Hem'u'l-hevâmi', 1: 394, 457; 2: 331; İbnü'1-Haşşâb, el-Mürtecel fì şerhi'l-Cümel, 227, 234; Şevki Dayf, el-Medârisu'n-nahviyye (Kahire: Dâru'lmaârif, 1968), 218.

19 Şâtıbî, el-Mekâsıdü'ş-şâfiye, 6: 199; Muhammed Bedurddin b. Ebîbekr b. Ömer Demâmînî, Ta'lîku'l-ferâid alâ Teshîli'lfevâid, nşr. Muhammed b. Abdurrahman b. Muhammed el-Müfdî, 1983, 4: 59; Ezherî, Şerhu't-Tasrîh ale't-Tavzîh, 1: 338; Sabbân, Hâşiyetu's-Sabbân, 1: 452.

${ }^{20}$ Verrâk, 'Ilelu'n-nahv, 257; Süheylî, Netâicu'l-fiker fi'n-nahv, 95. 
çerçevesinde şekillenmiştir. Yukarıda da ifade edildiği gibi nahivciler, harflerin "amel"ini ihtisâs olgusu çerçevesinde irdelemişler ve amel edebilmesi için bir durum veya dilsel ögeye özgü olmasını şart koşmuşlardır. Bu bağlamda isim veya fiilden birine özgü olan harfin özgün olduğu öge üzerinde amel etme hakkına sahip olacağını; isme özgü olan harfin hakkının cer etmek (cer'in isimlere özgü olmasına dayanarak), fiile özgü olan harfin hakkının da cezm etmek (cezmin fiillere özgü olmasına dayanarak) ve isim ve fiil arasında müşterek olan harfin hakkının ise amel etmemek olduğunu beyan etmişlerdir. Söz gelimi min (مِنْ) harfi isimlere özgü olduğundan cer, lem (لّْ) harfi fiillere özgü olduğundan cezm etmiştir. İsim ve fiil arasında müşterek olan hel (هلْ) ise herhangi birine özgü olmadığından amel etmemiştir. Genel bir ilke olarak kabul edilen aslî durum budur. Dolayisıyla bu genel ilkeye uygun olarak gelen kullanımlar için bir illet aranmayacağı, bir neden arayışına girilmeyeceği söylenmiştir. Cümledeki değişimin bu eksende olmaması halinde söz konusu değişimin nedeni tartışma konusu yapılmıştır. Harflerin isme özgü olduğu halde cer dışında amel etmesi, fiile özgü olduğu halde cezm dışında amel etmesi ve her ikisi için müşterek olduğu ve amel etmemesi gerektiği halde amel etmesi, sadece fiile veya sadece isme özgü olduğu halde amel etmemesine yönelik kullanımlar aslî ilkenin dışındaki diğer ihtimallerdir. Asıl kuralın dışında kalan bu tür kullanımlarda da aslın dışına çıkmalarının illeti aranmıştır. Bu illet arayışı, çoğu zaman olması gereken durumun dışına çıkan ögenin bir başka ögeye bir veya birkaç noktada benzerlik gösterdiği ifade edilerek sonuçlanmıştır. ${ }^{21}$

Burada öncelikle bu beş istisnai durum ile ilgili yorumlara yer verilecek, ardından 'âmil ve ihtisâs ilişkisi kapsamına giren diğer tartışmalı örneklere temas edilecektir.

a. Asıl ilkenin dışına çıkan ve ameli ile ilgili ayrı bir izah gerektiren durumların ilki isme özgü olduğu halde cer dişında amel eden harflerle ilgili olarak zikredilen inne ve gurubudur. Bu harflerin cer etmeyip nasb ve ref etmesinin gerekçesi; harf sayısı ve anlam bakımından fiillere benzemeleridir.

b. Bunların ikincisi fiile özgü olduğu halde cezm dışında amel etme durumudur ki buna da muzâri fiili nasb eden harfler örnek verilmiştir. Bu harflerin nasb etmelerinin illeti len (لنْ) edatının anlam bakımından cinsten hükmü nefyeden lâ'ya (لا) benzetilmesi ve diğerlerinin de buna dâhil edilmesidir. ${ }^{22}$

c. Üçüncüsü ise isim ve fiil arasında müşterek olduğu halde amel eden harflerin durumudur. Bunlara ismini ref, haberini nasb eden mâ (ما) ve lâ örnek verilmiştir. Nitekim mâ'nın amelinden söz edilirken kıyâs gereği amel etmemesi gerektiği belirtilmiştir. Zira mâ hem isme hem de fiile dâhil olur. 'Âmillerde asıl olan, bir ögenin başka bir ögede 'âmil olması için bir türe bağlı kalması, ona ayrılmamak üzere ilişmesi ve "istibdâd" kurmasıdır. Söz konusu mâ ise isim veya fiilden birine bağlllı̆̆ı ağır basan bir öge değildir. Ancak amel ettiğine dair

\footnotetext{
21 İbn Hişâm, Evdahu'l-mesâlik, 1: 25, 26; Sabbân, Hâşiyetu's-Sabbân, 1: 89-92; İbn Ya'îş, Şerhu'l-Mufassal, 1: 243.

22 Burada şu noktaya temas etmekte yarar vardır. Asıl itibariyle fiile özgü olan harflerin cezm etmesi gerektiği belirtilmiştir. Harf olan لن de fiile dâhil olduğu halde nasb etmiştir. Bu duruma gerekçe olarak نُ'in cinsten hükmü nefyeden لا لya benzemesi gösterilmiştir. Ancak buradaki duruma gerekçe olarak gösterilen benzerlik ilişkisi konuyu izah etmek için yeterli görünmemektedir.
} 
birçok kullanımının bulunması kıyâsın dışında başka bir açıklama biçimini gerekli kılmıştır ki mâ'nın leyse'ye (َلَّنَ) benzemesi ilke dışı kullanımın gerekçesi olarak zikredilmiştir. ${ }^{23}$

d. İstisnai durumların dördüncüsü ise bazı harflerin fiile has olmalarına rağmen amel etmemeleridir. Bunlara qâd (قدا) (سبن) vîn) ve sevfe (سوف) örnek verilmiştir. Zira bu harfler sadece fiile dâhil oldukları halde amel etmezler. Amel etmemesine gerekçe olarak bu harflerin fiilden bir parça olduğu ve bir şeyin parçasının bütünü üstünde amel edemeyeceği gösterilmiştir. Süheylî de sîn ve sevfe'nin muzâri fiile özgü olduğu halde muzâri fiile özgü olan diğer harfler gibi neden amel etmediğini sorgularken şu izaha yer vermiştir: "Bu harfler muzâri fiilin şimdiki zaman anlamı ile gelecek zaman anlamı arasındaki ayrıma işaret etmek üzere getirilmekte olduğundan ayırt edicilik özelliğine sahiptirler. Dolayısıyla muzâri fiile özgü olması amel etme gerekçesi olmamış, fiilin kendi içindeki anlam farklılıklarının işareti olmuştur."24

e. Bu durumların beşincisi ve sonuncusu ise bazı harflerin isme has olduğu halde amel etmemeleridir. Buna isimlere bitişen el (ال) takısı örnek verilmiştir. Bu harfler sadece isme bitiştiği halde amel etmezler. Yine bunda da aynı gerekçe ileri sürülmüş ve bu takının ismin bir parçası sayıldığı, bu takının bulunup bulunmamasının başa gelen 'âmilin amel etmesinde bir engel oluşturmadığı söylenmiştir. Ayrıca isim veya fiilden birine özgü olan her edatın 'âmil olmayacağı, amel etmek için ihtisâs dışında başka bir anlama daha ihtiyaç duyulacağı ve bunun da söz konusu edatın fiile benzeme derecesine bağlı olduğu belirtilmiştir. ${ }^{25}$

\section{3. İHTISÂS TARTIŞMALARININ ÖNE ÇIKTIĞI HUSUSLAR}

$\mathrm{Bu}$ genel girişten sonra ihtisâs olgusu çerçevesinde tartışılan durumları ele almak yerinde olacaktır.

\section{1. İnne (إنَّ) ve Benzerleri}

Daha önce ifade edildiği gibi inne ve benzerlerinin haberlerinin 'âmili, dilcilerin tartıştığı bir konudur. Bilindiği üzere inne ve benzerleri, mübtedâ ve haber yapısının başında kullanılır ve mübtedâ olan kelime artık inne'nin ismi olup mansûb olarak i'râb edilirken haber yine haber ve merfû olarak kalmaktadır. Burada Kûfeli dilciler inne'nin, ismini nasb etse de haberinde amel etmeyeceğini belirtmişlerdir. Kisâî'ye göre durum böyle olsa da Ebû Osmân elMâzinî bunu kabul etmemiş ve Halîl b. Ahmed'e göre inne'nin her ikisinde 'âmil olduğunu söylemiştir. ${ }^{26}$ 'Ukberî de bu harflerin hem isme özgü olduklarını hem de iki isim gerektirdiklerini ve bu nedenle her ikisinde de 'âmil olduklarını belirtmiştir. Çünkü bu harfler fiile benzediklerinden dolayı amel etmişlerdir. Fiil ise hem fâilini hem de mef'ûlünü etkilemektedir. Buna bağlı olarak bu harflerin de tıpkı fiil gibi hem isminde hem de haberinde amel etmeleri gerekmektedir. Ayrıca bu harflerin sözün bir kısmına (isim veya fiile) özgü

\footnotetext{
${ }^{23}$ Verrâk, 'Ilelu'n-nahv, 257; İbn Hişâm, Evdahu'l-mesâlik, 1: 25, 26.

${ }^{24}$ Süheylî, Netâicu'l-fiker fi'n-nahv, 95; Sabbân, Hâş̧iyetu's-Sabbân, 1: 89-92; “Ukberî, el-Lübâb, 1: 207, 208; Nâzıru'l-Ceyş, Temhîdu'l-kavâld, 3: 1302, 1303.

25 İbn Hişâm, Evdahu'l-mesâlik, 1: 25, 26; Ebu'l-Bekâ Muhibbuddîn Abdullah b. Hüseyin "Ukberî, et-Tebyîn an mezâhibi'nnaĥtviyyîne'l-Baśriyyîn ve'l-Kûfiyyîn, nşr. Abdurrahman b. Süleyman el-Useymin (Beyrut: Dâru'l-garb el-İslâmî, 1976), 243; el-Lübâb, 1: 207, 208; Sabbân, Hâşiyetu's-Sabbân, 1: 89-92.

${ }^{26}$ Ebu'l-Kâsım Abdurrahman b. İsmail Zeccâcî, Mecâlisu'l-ulemâ, nşr. Abdüsselâm Muhammed Hârun (Kuveyt: Matbaat'u-Hukûmet'i-Kuveyt, 1984), 132.
} 
oldukları için amel ettiklerini, bir şeyin başka bir şeye özgü olmasının o şeyin tesir gücüne delil olduğunu, manaya tesir eden bir ögenin lafza da tesir etmesi gerektiğini belirtmiştir. ${ }^{27}$

Görüldüğü üzere bu harf, dâhil olduğu her iki ögede 'âmil olup olmadığı tartışılsa da özgün olma şartını sağladığından 'âmildir. Ancak çeşitli değişimlere maruz kalması halinde farklı durumlar ortaya çıkmaktadır. Zira inne'nin şeddeli nûn (ن) harfinden birinin atılması (tahfîf) ve in (إنْ) ş̧ekline dönüşmesi ve aynı gurupta yer alan bütün harflere mâ harfinin (mâ-i kâffe) bitişmesi durumlarında isim veya fiilden birine özgü olma durumu tartışmalı hale gelmektedir. Söz gelimi eklendiği kelime gurubu üzerinde herhangi bir ameli bulunmayan mâ, inne ve benzerlerine birleştiğinde eklendiği cümle gurubu üzerindeki etkisini yok etmiştir.

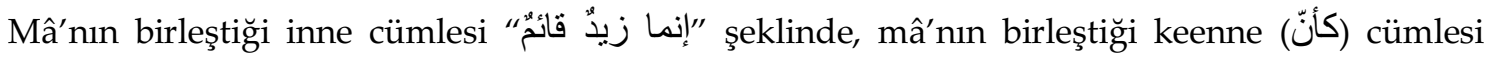

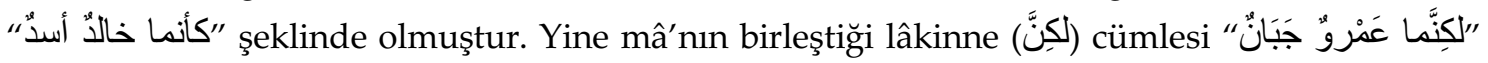

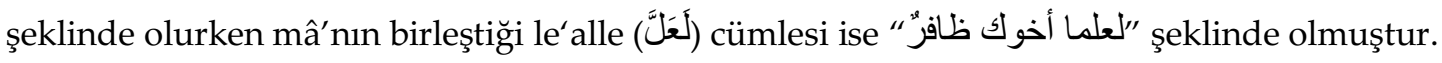

Burada söz konusu harflerin amel etmesine imkân kalmamıştır. Çünkü önlerine getirilen mâ, onların isimlere özgü olma durumunu ortadan kaldırmıştır. Söz konusu harfler, mâ'nın dâhil olmasıyla isme özgü olma şartını yitirmiş ve hem isme hem de fiile dâhil olabilecek duruma gelmiştir. Zira amel etmenin şartının ihtisâs olduğu, isim ve fiil üzerinde müşterek olmanın amelin iptalini gerektirdiği ilkesi asıldır. Yani bir edatın amel etmesi özgün olmasına bağlı iken özgünlügünü kaybedip müşterek bir özellik kazanmasıyla amel etme

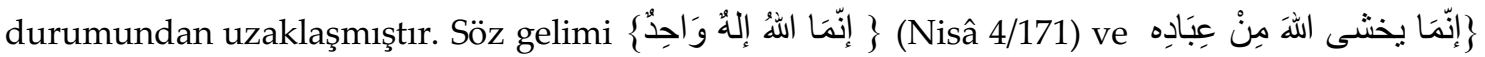

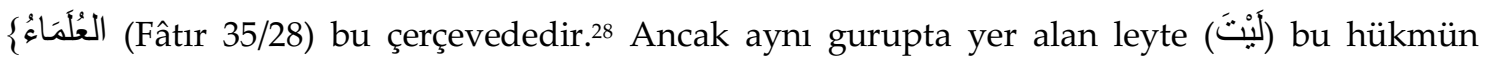

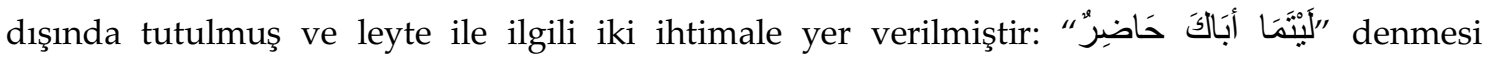

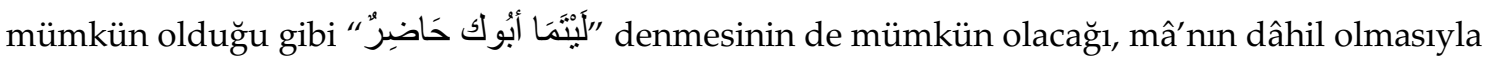
leyte'nin isme özgü olma durumunun ortadan kalkmadığı belirtilmiştir. Buna bağlı olarak amel ettirilmesinin mümkün olduğu gibi ayn gurupta olan diğer edatlara kıyâsla amel ettirilmemesinin de mümkün olduğu ifade edilmiştir.29

İnne'nin amelini tartışmalı noktaya getiren bir başka durum da inne'nin in şekline dönüşmesidir (tahfîf). İnne, mübtedâ ve habere özgü bir harftir. İn şekline dönüşüp zayıfladığında ve mübtedâ ve habere özgü olma durumu ortadan kalktığında amel edip etmemesi tartışmalı hale gelmiştir. ${ }^{30} \mathrm{Bu}$ durumda isme has olma durumu ortadan kalkmıştır.

\footnotetext{
27 “Ukberî, et-Tebyîn, 264, 265; el-Lübâb, 1: 207, 208. Geniş bilgi için bk. İbn Ya'îş, Şerhu'l-Mufassal, 1: 254.

28 İbnü'l-Haşşâb, el-Mürtecel fì şerhi'l-Cümel, 229; Endelûsî, et-Tezyîl ve't-tekmîl, 5: 158, 159.

29 İbnü'n-Nâzım, Şerhu İbn Nâzım, 124, 125; İbn Ya'îşs, Şerhu'l-Mufassal, 4: 521, 525; İbn Kayyim el-Cevziyye, İrşâdü's-sâlik, 242-244; İbn Mâlik, Şerhu't-teshîl li İbn Mâlik, 2: 38; İbn Mâlik, Şerhu'l-kâfiye, 1: 479, 480; 2: 616; Ebû Muhammed Abdullah Cemâlüddîn İbn Hişâm, Tahlîsu's-şevâhid ve telhîsu'l-fevâid, nşr. Abbâs Mustafa es-Sâlihî (Beyrut: Dâru'l-kitâbi'l-Arabî, 1986), 362; İbn Hişâm, Evdahu'l-mesâlik, 1: 347-349; Ebû Muhammed Bahâüddîn Abdullah İbn Akîl, Şerhu İbn-i Akîl, nşr. Muhammed Muhyiddin Abdulhamîd (Kahire: Dâru't-türas, 1980), 1: 373, 374; Süyûtî, Hem'u'l-hevâmi', 1: 458, 459; Abbâs Hasan, en-Nahvu'l-vâfí (Kahire: Dâru'l-maârif bi Misra, ts.), 1: 636; Endelûsî, et-Tezyîl ve't-tekmîl, 5: 149, 150; Nâzıru'l-Ceyş, Temhîdu'l-kavâld, 3: 1367, 1370; Şâtıbî, el-Mekâsıdü'ş-şâfiye, 2: 359, 364; Demâmînî, Ta'lîku'l-ferâid alâ Teshîli'l-fevâid, 4: 299; Ebu'l-Hasen Nûruddîn Alî b. Muhammed b. Îsâ b. Yûsuf Üşmûnî, Şerhu'l-Üşmûnî alâ Elfiyeti'bni Mâlik el-müsemmâ Menhecü's-sâlik ilâ Elfiyyeti'bni Mâlik, nşr. Muhammed Muhyiddin Abdulhamîd (Beyrut: Dâru'lkütübi'l-Arabî, 1955), 1: 133, 134; Ezherî, Şerhu't-Tasrîh ale't-Tavzîh, 1: 316, 317; Süyûtî, Hem'u'l-hevâmi', 1: 459. Bu konuda farklı görüşlere de yer verilmiştir. Endelûsî, et-Tezyîl ve't-tekmîl, 5: 149. İbn Akîl bu harflerin amel etmesi ile ilgili nahivcilerin iki gurupta olup Zeccâcî, İbn Serrâc, Ahfeş ve Kisâî'nin amel etmesinden yana olduğunu ve amel etmemesi taraftarı olanların görüşünü daha doğru bulduğunu belirtmiştir. Bk. İbn Akîl, Şerhu İbn-i Akîl, 1: 373, 374.

30 Sabbân, Hâşiyetu's-Sabbân, 1: 452.
} 
Basralı dilcilere göre in'den sonra isim bulunursa in edatının muhaffef olarak amel etmesi

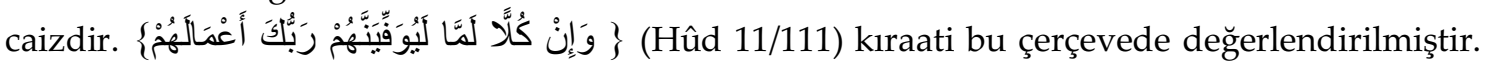

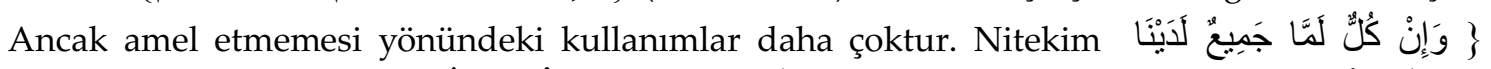

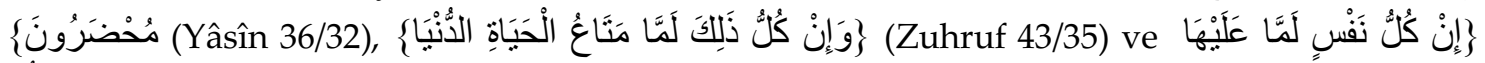
حَفِفظٌ (Târık 86/4) âyetleri buna örnektir. Kûfelilere göre ise bu harfin ameli yoktur ve söz konusu harf (in), inne'nin muhaffef hali değildir. Aslında bu edat bir olumsuzluk (nefy) harfidir. ${ }^{31}$

Hakeza aynı gurupta yer alan enne (أنّ) (أنْ) se kimi zaman dine dönüşür. Bu durumda amel edip etmeyeceği ile ilgili çeşitli görüşler vardır. Sîbeveyh'e (ö. 180/796) ve Kûfeli

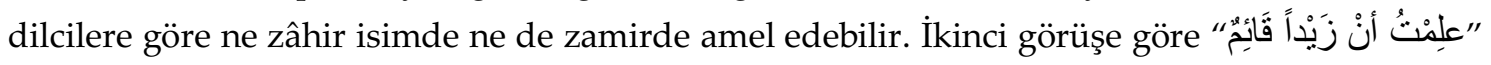
cümlesinde olduğu gibi zamirde de zâhir isimde de amel edebilir. Üçüncü görüşe göre zamirde amel etmesine cevaz verilebilir. Ancak isimde amel etmesi mümkün değildir. Genel kanaat de bu yöndedir. Amel etmesi için şart olan ihtisâs olgusu devam ettiğinden amel etme durumu da devam etmektedir. ${ }^{32}$

İnne'nin haberinde yer alan ve te'kîd için getirilen lâm $\left({ }^{\lrcorner}\right)$ile ilgili tartışmalara bakıldığında yine ihtisâs olgusu önemli bir noktada dile getirilerek sorun çözümlenmektedir.

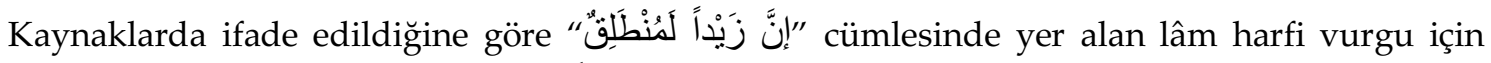
getirilmiştir. Cümle aslında " şeklinde iken aynı manadaki (te'kîd manası) iki harfin (lâm ve inne) bir araya gelmesi uygun bulunmamış ve lâm harfi habere taşınmıştır.

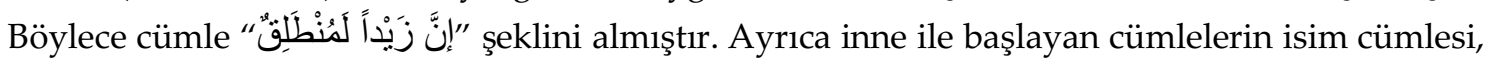
fiil cümlesi ve şibh cümle gibi haber türlerine de dâhil olması sorun olmamıştır. Bu noktada şöyle bir soru gündeme gelmiştir: Eğer lâm'ın habere bitiştirilmesinden amaç, aynı manada kullanılan lâm ile inne'yi birbirinden ayırmak ise neden lâm başa, inne sona alınmamıştır? Burada en önemli gerekçe inne' nin sadece isimlerde 'âmil olmasıdır. Eğer lâm başta bırakılacak ve inne habere birleştirilecek olsa bu durumda inne'nin isim, fiil, cümle gibi farklı haber türlerine birleşmesi söz konusu olacak ve bu da inne'nin amelinin iptal edilmesine yol açacaktır. $\mathrm{Bu}$ durumda kelime guruplarından birine özgü olma şartını yitirecektir. Lâm için böyle bir

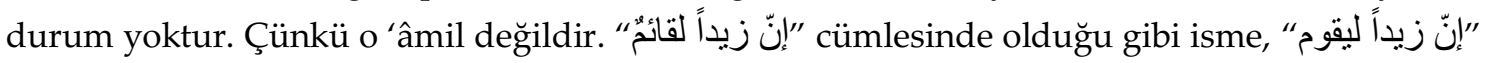
cümlesinde olduğu gibi fiile ve birleşmesinde sorun yoktur. Aksi mümkün değildir. ${ }^{33}$

\section{2. İstisnâ Edatı Olan (إلإ)}

İhtisâs olgusu ile irtibatlı olan ve 'âmil olup olmadığı aynı çerçevede tartışılan bir diğer harf, istisnâ edatı olan illâ'dır. İstisnâ edatlarından illâ'nın 'âmil olmasından söz edilirken söz konusu edatın müstakil olarak mı yoksa önceki ögelerden biri ile mi 'âmil olduğu meselesi gündeme gelmiş, bu edatın isimlere has olması nedeniyle başlı başına, müstakil bir 'âmil olduğu ve bu nedenle 'âmil olmasının başka bir vasıtaya bağlı olmadığı belirtilmiştir. ${ }^{34}$ Söz

\footnotetext{
31 Süyûtî, Hem'u'l-hevâmi', 1: 450, 451; İbn Mâlik, Şerhu't-teshîl li İbn Mâlik, 2: 34, 35; İbnü'n-Nâzım, Şerhu İbn Nâzım, 128; Nâzıru'l-Ceyş, Temhîdu'l-kavâtd, 3: 1361; Üşmûnî, Şerhu'l-Üşmûnî, 1: 144, 145; Ezherî, Şerhu't-Tasrîh ale't-Tavzîh, 1: 326, 327.

32 Süyûtî, Hem'u'l-hevâmi', 1: 453, 454.

33 İbn Ya'îş, Şerhu'l-Mufassal, 5: 146, 147.

34 Sabbân, Hâşiyetu's-Sabbân, 2: 210, 211; İbnü'n-Nâzım, Şerhu İbn Nâzım, 213-215.
} 
gelimi Müberred (ö. 286/900) ve Zeccâc'a (ö. 311/923) göre müstesnânın 'âmili illâ'dır. ${ }^{35}$ Aksi yönde zikredilen görüşlere göre ise illâ'nın isimlere özgü olma durumu olmadığından

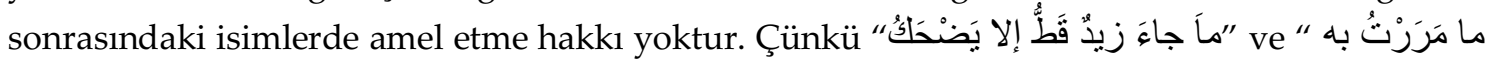
cümlesinde olduğu gibi harfe dâhil olmuştur. Hem isme hem de fiil ve harfe dâhil olabilen bir harfin 'âmil olması mümkün değildir. Bu nedenle başta Sîbeveyh olmak üzere Basralı dilcilere göre müstesnâyı illâ değil de

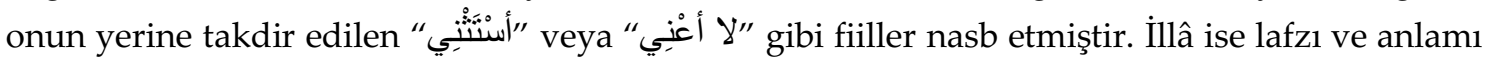
güçlendirmek üzere getirilmiştir. ${ }^{36}$

Bu iki zıt görüş şu şekilde tevil edilmiştir: İllâ isme özgü bir harftir. Bu nedenle 'âmil olmasında bir sakınca yoktur. İsim dışındaki ögelere dâhil olduğu durumlarda ilgili kullanımlar isim tevilindedir ve isim tevilinde olduğu zaman fiile de bitişebilir. Bu durumda isim tevilindeki fiile bitişmesi onun isme özgü olmasına halel getirmeyecek, bu da ameline engel olmayacaktır. ${ }^{37}$ İbn Mâlik'e (ö. 672/1274) göre de illâ isme özgü olduğundan 'âmildir. Söz konusu edatın fiile dâhil olması konusunda da şöyle denmiştir: “Illầ'nın önüne geldiği fiil, isim

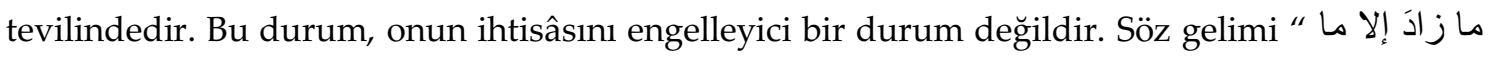
demektir. İlâ'nın dâhil olduğu fiillerin tamamı isim tevilindedir. Eğer isme özgü olan bir ögenin fiile dâhil olması ihtisâs durumunu ortadan kaldırıp ameline mani olsaydı isim, fiile izâfe edilemezdi, ظُnin ikinci mef'ûlü, كان ve inne'nin haberi fiil olamazdı. Çünkü bunlar üzerinde etki eden 'âmiller, isme özgü 'âmillerdir. Dolayısıyla bu 'âmillerin fiil üzerine de gelebilmeleri ihtisâs durumlarına zarar vermediğine göre illâ'nın fiile dâhil olması onun ihtisâsına ve ameline zarar vermez. ${ }^{38}$

\subsection{Levlâ (لولا)}

Dilcilerden levlâ'dan sonraki merfû ismin 'âmili ile ilgili nakledilen tartışmalarda da aynı şekilde söz konusu olgunun temel bir gerekçe olarak dile getirildiğini görürüz. Kûfeli dilcilere göre "لو لا زيدٌ لأكرمنتُكَّimlesinde yer alan levlâ, kendisinden sonraki ismi ref eder ve dolayısıyla buradaki 'âmil levlâ'dır. Basralı dilcilere göre ise söz konusu ismin merfû olmasının sebebi mübtedâ olmasıdır. Onlara göre levlâ 'âmil olamaz. Çünkü harfler, isim veya fiilden birine özgü olduğunda 'âmil olabilirler. Levlâ ise ne isme ne de fiile özgüdür. Hem isme hem de fiile bitişebilir. Buna göre 'âmil olmaması gerekmektedir. Levlâ'nın 'âmil olması mümkün olmadığına göre ondan sonraki isim, mübtedâ olduğundan dolayı merfûdur. İbnü'l-Enbârî bunu kabul etmemiş ve levlâ'nın fiillere değil de isimlere özgü olduğunu ve buna bağlı olarak 'âmil olması gerektiğini belirtmiştir. ${ }^{39}$

Levlâ'nın amel edip etmeyeceği ile ilgili tartışmalarda dile getirilen bir durum konuya farklı bir bakış açısı getirmektedir: Levlâ'nın 'âmil olduğunu savunanlara göre levlâ, isme özgüdür ve aynı şartı taşıyan diğer harfler gibi amel etmelidir. Bu nedenle levlâ da amel etmiş

\footnotetext{
35 İbnü'l-Enbârî, el-i̇nsâf, 1: 212.

36 İbn Ya'îş, Şerhu'l-Mufassal, 2: 46, 47; 4: 456, 457.

37 İbnü'n-Nâzım, Şerhu İbn Nâzım, 214; Endelûsî, et-Tezyîl ve't-tekmîl, 8: 197.

38 Endelûsî, et-Tezyîl ve't-tekmîl, 8: 196, 197; Şâtıbî, el-Mekâsıdü'ş-şâfiye, 3: 350, 351; İbnü'n-Nâzım, Şerhu İbn Nâzım, 214; İbn Mâlik, Şerhu't-teshîl li İbn Mâlik, 2: 274.

39 İbnü'l-Enbârî, el-İnsâf, 1: 60-65; İbn Ya'îş, Şerhu'l-Mufassal, 5: 90.
}

|198|

Hitit Üniversitesi İlahiyat Fakültesi Dergisi, 2019/1, Cilt: 18, Sayı: 35 
ve sonraki ismi ref etmiştir. Böylece isme özgü olduğundan sadece ref etkisine sahip olmuş, nasb etmemiştir. Bu görüşe iki açıdan itiraz edilmiştir: Öncelikle levlâ'nın isme özgü olması kabul edilmemiş, levlâ'nın fiile de dâhil olduğu belirtilmiştir. Levlâ'nın isme özgü olduğu kabul edilse bile ihtisâs şartını taşıyan her ögenin 'âmil olamayacağı belirtilmiştir. Nitekim el takısı sadece isimlere bitiştiği halde 'âmil olmadığı, 'âmil olması için ihtisâs dışında başka bir manaya ihtiyaç duyduğu ifade edilmiştir. Bu mana ise fiile benzeme gücüdür. Levlâ için bu derece bir benzerlik mümkün görülmemiştir. ${ }^{40}$ Levlâ'nın amilliği ile ilgili bir diğer sorunlu nokta da şuradadır: İsme özgü amillerin cer edeceği daha önce belirtilmiştir. Şayet levlâ'nın isme özgü olduğu kabul edilecek olursa kendisinden sonra gelen kelimeyi neden ref ettiği sorgulanacaktır. Bir başka deyişle isme özgü olmakla 'âmillik vasfına kazandığı belirtilen bir ögenin cer yerine ref etmesi, kendisinden sonra gelen kelimenin 'âmili hakkındaki soru işaretlerini ortadan kaldırmaya yetmeyecektir.

\subsection{Mâ (ما)}

İhtisâs durumu dolayısıyla 'âmil olup olmadığı tartışılan bir diğer harf de mâ'dır. Mâ, olumsuzluk anlamı içeren bir harf olup hem isimlerin hem de fiillerin başına gelebilir. O halde kıyâs gereği amel etmemesi gerekir. Çünkü isimlerin 'âmilleri fiilere, fiillerin 'âmilleri isimlere

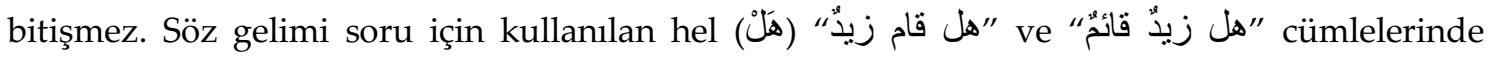
olduğu gibi hem isme hem de fiile dâhil olmuştur. İsim ve fiile özgü olmadığından amel etmesi

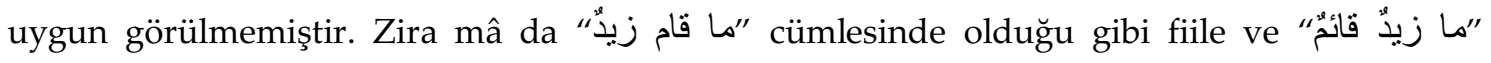
cümlesinde olduğu gibi isme dâhil olmuştur. Kıyâsa uygun olan, mâ'nın amel etmemesidir. Temîm kabilesi bu nedenle amel ettirmemiştir. Buna göre "زيد “ mübtedâ, "قائم" ise haberdir. Mâ'nın iki kelime üzerinde de bir etkisi yoktur. ${ }^{41}$ Hicâz kabilesine göre ise mâ amel bakımından leyse'ye dâhil edilmelidir. Çünkü mâ; olumsuzluk, haberine bâ (ب) harfinin bitişmesi, mübtedâ ve haberin önünde kullanılma gibi yönlerden leyse'ye benzemektedir. Bir şey, başka bir şeye bir veya daha fazla yönden benzediğinde anlamı bozmadığı sürece ona hamledilir. Bu benzerlikten dolayı mâ, mübtedâ ve haberde leyse gibi

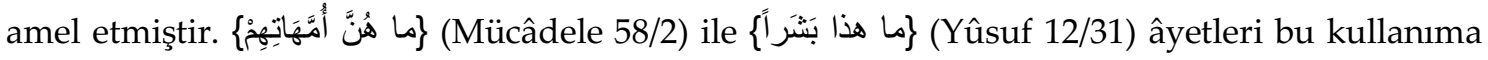
göredir. ${ }^{42}$ Görüldügü üzere Hicâz lehçesinde mâ, isim ve fiil arasında müşterek olmasına rağmen amel etmiştir. Buna leyse'ye benzemesi gerekçe gösterilmiştir. Bu nedenle mâ'nın leyse'ye benzerlik yönü olan olumsuzluk anlamı ortadan kalkınca amel etmesi için bir gerekçe kalmayacağı belirtilmiştir.43 İbn Ya'îş (ö. 643/1245) mâ'nın amel etmemesi yönündeki Temîm lehçesine ait uygulamayı kıyâsa uygun bir uygulama olarak görürken Hicâz lehçesinin uygulamasını da fasih bir uygulama olarak değerlendirmiştir. ${ }^{44}$

\subsection{Muzâri Fiilin Mansûpluğu}

İhtisâs olgusuyla irtibatlı olarak ele alınan bir diğer konu da muzâri fiilin nasbı ile ilgilidir. Muzâri fiilin fâ (ف), ev (أو), vâv (واو), lâm (ل) ve hattâ (حتى) harflerinden sonraki nasb1

\footnotetext{
40 “Ukberî, et-Tebyîn, 146-149; İbn Ya'îş, Şerhu'l-Mufassal, 1: 243.

41 “Ukberî, el-Lübâb, 1: 175; İbnü'n-Nâzım, Şerhu İbn Nâzım, 213-215.

42 İbn Mâlik, Şerhu't-teshîl li İbn Mâlik, 1: 369; Nâzıru'l-Ceyş, Temhîdu'l-kavâtd, 3: 1190, 1191; İbnü'n-Nâzım, Şerhu İbn Nâzım, 103, 104, 213-215; İbn Akîl, Şerhu İbn-i Akîl, 1: 302; ‘Ukberî, el-Lübâb, 1: 175.

43 Demâmînî, Ta'lîku'l-ferâid alâ Teshîli'l-fevâid, 3: 241, 242.

44 İbn Ya'îş, Şerhu'l-Mufassal, 1: 268.
} 
sıkça tartışılmıştır. Bu harflerin tamamının isme veya fiile özgü olma konusunda yetersiz görülmesi kendilerinden sonra gelen muzâri fiilin nasbına neden olan 'âmilin tam olarak ne olduğu sorusunu gündeme getirmiştir. Muzâri fiilin ev, vâv ve fâ'dan sonra mansûb olması konusu üzerinde duran dilciler bu harflerin hem isme hem de fiile dâhil olduklarını, hem isme hem de fiile dâhil olan harfler özgün olmadıklarından isim veya fiilden birinde 'âmil olamayacağını belirtmişlerdir. Bu nedenle muzâri fiilde görülen nasb, izaha muhtaç görülmüş ve fiilin gizli bir en ile mansûb olduğu fikri yaygın bir kanaat olarak öne çıkmıştır. Bu görüş Sîbeveyh ${ }^{45}$, İbn Serrâc ${ }^{46}$, İbn Verrâk ${ }^{47}$ (ö. 365/976) ve diğer Basralı dilciler tarafından savunulmuştur. ${ }^{48}$ Ferrâ (ö. 207/822) bu harflerden sonra gelen fiillerin "hilâf" nedeniyle mansûb olduğunu söylerken ${ }^{49}$ Kisâî (ö. 189/805) muzâri fiili bu harflerin nasb ettiğini söylemiştir. Ancak hem Ferrâ ve hem de Kisâî'nin dile getirdiği bu görüş yeterince ilgi görmemiştir.50

Mansûb muzâri fiil ile ilgili tartışılan diğer harfler ise muzâri fiili nasb eden harflerden sayılan lâm ve hattâ'dır. Aynı şekilde lâm harfi de asıl itibariyle isimlere özgü bir harftir. Bu nedenle fiile özgü olmadığı halde hem muzâri fiile dâhil olması hem de muzâri fiili nasb etmesi izaha muhtaç bir durum olarak değerlendirilmiştir. Bu meselede de varsayıma (takdîr) başvurularak J'dan sonra gizli bir en bulunduğu belirtilmiş ve hatta gizli en'in takdir edilmesi zorunlu görülmüştür. ${ }^{51}$ Hattâ'nın muzâri fiili nasb etmesinden söz edilirken de Basralı dilciler muzâri fiilin hattâ'dan sonra zorunlu olarak gizlenen en ile mansûb olduğunu söylemişlerdir. Buna hattâ'nın ismi cer eden harfler arasında sayılmasını gerekçe göstermişlerdir. Süyûtî buradan yola çıkarak hattâ'nın muzâri fiili nasb etme yetkisini yitirdiğini belirtmiş ve gerekçe olarak isimlerin 'âmillerinin fiillerde 'âmil olamayacağını, bunun özgün olma durumuna aykırı olduğunu belirtmiştir. ${ }^{52}$

\subsection{Diğer Harfler}

Ma'tûfun 'âmili konusunda dile getirilen tartışmalar da bu çerçevede incelenebilir. Nitekim Sîbeveyh ve Basralı dilcilerden bir guruba göre atıf harfi ile sıralı her iki ismin 'âmili

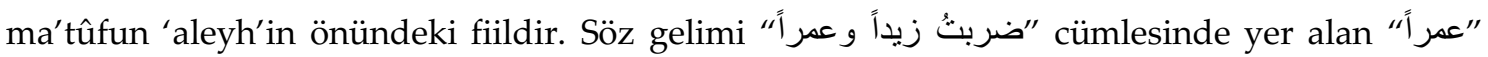
kelimesinin 'âmili " kريد" fiilidir. Her iki kelime de bu fiilden dolayı mansûb olmuştur. Atıf harfi araya girmiş ve aralarında ortak bir ilişki kurmuştur. İbnu'sSerrâc'a (ö. 316/929) göre ise ilkinin 'âmili fiil iken ikincisinin 'âmili atıf harfidir. Buna göre atıf harfi, 'âmilin tekrar edilmesinin önüne geçmek üzere 'âmilin yerine getirilmiştir. Nitekim "قام "قدو' "قام " diilinin tekrar edilmesine gerek bırakmamış ve böylece aynı şekilde amel etmiştir. Ancak İbn Ya'îş buna karşı çıkmış ve yine aynı gerekçeyi ileri sürerek şöyle demiştir: “'Âmil ma’mûlüne özgü olmak zorundadır. Atıf

\footnotetext{
45 Sîbeveyh, el-Kitâb, 3: $41 \mathrm{vd}$.

${ }^{46}$ İbn Serrâc, el-Usûl fi' $n$-nahv, 2: 153 vd.

47 Verrâk, 'Ilelu'n-nahv, 195.

48 İbn Ya'îş, Şerhu'l-Mufassal, 4: 232, 233; Şemsuddîn Muhammed b. Muhammed 'Abdulmün'ım Cevcerî, Şerhu Şüzûri'zzeheb, nşr. Nevvâf Cezâ el-Hârisî (Medine: Câmiatu'l-İslâmiyye, 2004), 2: 540 vd.

${ }^{49}$ İbn Ya'îş, Şerhu'l-Mufassal, 4: 232 vd.

50 İbnü'1-Enbârî, el-İnsâf, 2: 452; Cevcerî, Şerhu Şüzûri'z-zeheb, 2: 540.

${ }^{51}$ Nâzıru'l-Ceyşs, Temhîdu'l-kavâld, 8: 4170, 4171.

52 Süyûtî, Hem'u'l-hevâmi', 2: 298, 300.
}

$|200|$

Hitit Üniversitesi İlahiyat Fakültesi Dergisi, 2019/1, Cilt: 18, Sayı: 35 
harfi ise isim veya fiilden herhangi birine özgü olmayıp her ikisine de dâhil olabilir. Bu nedenle isim veya fiilde amel etmesi doğru değildir."53

Aynı gerekçelerle 'âmil olmasına imkân tanınmayan harflerden biri de mef' ûlü maah kullanımında yer alan vâv'dır. Vâv' dan sonraki kelimenin 'âmili tartışmasında 'âmilin vâv harfi olduğu görüşüne söz konusu harfin aslen atıf harfi olduğu, atıf harflerinin isim veya fiilden birine ait olmayıp her ikisi için de kullanıldığı, dolayısıyla hem fiile hem harfe hem de isme aynı düzeyde bitişebilen bir harfin herhangi bir amelinin olamayacağı söylenerek karşı çıkılmıştır. Buna göre mansûb kelimenin 'âmilinin cümlede yer alan fiil olduğu söylenmiştir. Sîbeveyh'in görüşleri bu doğrultudadır. ${ }^{54}$

"Mâ, lâ ve in" harfleri de aynı şekilde ihtisâs şartını taşımadığı halde 'âmillik vasfına sahip harflerdendir. Bu harfler, kıyâs gereği isim veya fiilden bir guruba özgün

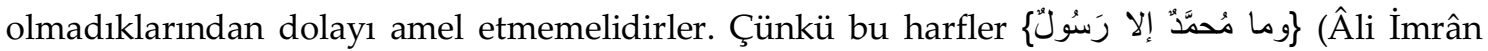

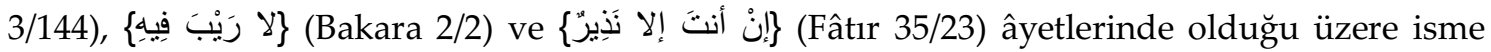
dâhil oldukları gibi aynı zamanda

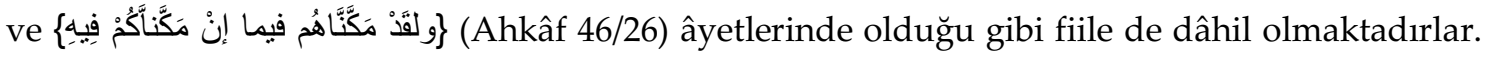
Dolayısıyla isim ve fiilden birine özgü kullanımları yoktur. Ancak olumsuzluk anlamı içermesi, mübtedâ ve habere dâhil olması gibi nedenlerle leyse'ye olan benzerliği güçlü olduğundan amel edebilmiştir. ${ }^{55}$

Buraya kadar zikredilen örneklerde de görüldüğü üzere sözünü ettiğimiz olgu bir kelimenin 'âmil olup olmadığı tartışmasında gündeme gelen temel bir kriter olarak yer almıştır. Ancak ilgili kriteri taşımadığ 1 halde 'âmil olduğu tespit edilen kullanımlarla ilgili farklı bir durum ortaya çıkmıştır. Çünkü ihtisâs şartını taşımayan bir ögenin 'âmil sayıldığına dair kullanımlarda cümledeki değişikliğe neden olan ögenin 'âmil olmasını sağlayacak başka nedenler aranmıştır. Asıl itibariyle 'âmil olmadığı halde çeşitli ortak yönleri dikkate alınarak başka bir 'âmil arasında kurulan benzerlik ilişkisi bu nedenlerin en sık başvurulanıdır. Ancak ihtisâs şartını taşımadığı halde başka bir ögeye benzediği için amel etmeleri mümkün görülen bu harflerin amelleri belirli şartlarla sınırlı tutulmuş ve bu şartlardan birinin bulunmaması halinde ameli geçersiz sayılmıştır. ${ }^{56}$ Ayrıca ihtisâs olgusu bir 'âmilin güçlü veya zayıf bir 'âmil olup olmadığını da belirleyen önemli bir etken olmuştur. Söz gelimi mâ özgün bir 'âmil olmamasına rağmen ona çeşitli sebeplerle amel ettirilmiştir. Ancak bu edat zayıf bir 'âmil olarak görülmüştür. Bu itibarla amel edip etmemesi konusunda ihtilaf edilen bir öge ile ilgili herhangi bir şüphe ortaya çıktığında söz konusu öge, amelini kaybetmiştir. ${ }^{57}$ Şart edatlarının 'âmilliği de bu çerçevede ele alınmış ve dâhil oldukları her edat üzerinde 'âmil olmadıkları, her fiili cezm etmedikleri belirtilmiştir. Çünkü şart edatları mâzi veya muzâri fiilden birine özgü değildiler. İsim ve fiilden birine özgü olmakla 'âmil olsa da fiil türleri arasında mâzi ve muzâriden birine

\footnotetext{
53 İbn Ya'îş, Şerhu'l-Mufassal, 5: 4.

${ }^{54}$ Sîbeveyh, el-Kitâb, 1: 297, 298; İbn Ya'îş, Şerhu'l-Mufassal, 1: 439, 440.

Ayrıca harflerin fiillerin manalarını isimlere ulaştırmak için getirildikleri, her harfin cümlede ya lafzen veya takdiren bulunan bir fiile bağlı olduğu ve bağlı olduğu fiilin anlamını sonraki isme taşımak ve fiilin anlamını güçlendirmek için getirildiği belirtilmiştir. Bk. İbn Ya'îş, Şerhu'l-Mufassal, 4: 456, 457.

${ }_{55}$ Süyûtî, Hem'u'l-hevâmi', 1: 39, 40; İbn Kayyim el-Cevziyye, İrşâdü's-sâlik, 207, 208; İbnü'n-Nâzım, Şerhu İbn Nâzım, 133; İbnü'l-Haşşâb, el-Mürtecel fî şerhi'l-Cümel, 175-177.

56 İbn Kayyim el-Cevziyye, İrşâdü's-sâlik, 207, 208; İbnü'l-Haşşâb, el-Mürtecel fì şerhi'l-Cümel, 175-177.

${ }^{57}$ Endelûsî, et-Tezyîl ve't-tekmîl, 4: 269.
} 
has olması yönünden tam olmadığından zayıf bir 'âmil sayılmıştır. Bir edata özgü olan 'âmil diğerlerinden güçlü görülmüştür. ${ }^{58}$

Benzer şekilde, cinsten hükmünü nefyeden lâ'nın zayıf bir 'âmil olduğu belirtilmiştir. Çünkü bu harf, isim ve fiil arasında müşterek bir harf olup hem isme hem de fiile dâhil olabilir. Bu nedenle kıyâs gereği amel etmemesi gerektiği halde amel ettiğine dair kullanımlara bakarak yapılan değerlendirmelerde zayıf bir 'âmil olduğu belirtilmiş ve amel etmesi için haberinin nekre olması ve isminden sonra zikredilmesi gibi bazı şartlar zikredilmiştir. ${ }^{59}$ Aynı çerçevede bir başka tartışmalı 'âmil de izen'dir (إِّنْن ). Muzâri fiili nasb eden "izen", fiillere özgü olmadığından amel konusunda nasb eden edatlar gurubundaki diğer edatların seviyesinde sayılmamış, bu nedenle amel edebilmesi için diğerlerinde zikredilmeyen ek şartlar zikredilmiş, bu şartları tamamlasa bile amel etmemesinin de caiz olacağı belirtilmiştir. ${ }^{60}$ Hatta Sîbeveyh, elKitâb'da amel etmediğine yönelik bir örneğe yer vermiştir. ${ }^{61}$

\section{SONUÇ}

Arap dilcileri dile ait verileri büyük bir titizlikle incelemişler, olabildiğince kapsamlı hükümler vermek için çalışmışlar ve verdikleri hükmün dışına çıkan durumları da mutlaka belli bir çerçeveye oturtmaya çalışmışlardır. Bu çerçevede geleneksel nahvin en temel kavramlarından olan 'âmil kavramı da nahiv ilmini şekillendirmiş ve nahvin sistematiğine yön vermiştir. Öte yandan bir kelimenin 'âmil olup olmadığı tartışmasında temel bir kriter olarak gündeme gelen ve 'âmil kavramıla birlikte ele alınan ihtisâs olgusu da kimi nahiv meselelerinde yönlendirici bir etkiye sahip olmuştur. Söz konusu olgu, bir ögenin âmil olup olmamasında belirleyici bir unsur olmuştur. Bu çalışmada Arap dilinin kelime guruplarından sayılan isim, fiil ve harf türlerinin 'âmillik vasfını kazanabilmesi için gerekli olan ihtisâs şartı tartışma konusu edilmiştir. Bu çerçevede görülmüştür ki isim, fiil veya harf türünün 'âmil kabul edilmesinin öncelikli şartı, kendisi dışındaki başka bir kelime türünden sadece birine özgü olmasıdır. Bu şartın yerine getirilmesi halinde 'âmil sayılması asıldır. Kıyâs, her kelime türünün neye özgü ise onda amel etmesini, birine özgü değilse amel etmemesini gerektirmiştir. Bu nedenle bir türe özgü olma şartını taşımayan bir ögenin 'âmil sayıldığına dair kullanımlarla ilgili gerekçe arayışlarına şahit olunmuştur. Nitekim nahiv eserlerinde isme özgü olduğu halde cer dişında amel eden ve fiile özgü olduğu halde cezm dışında amel eden harflerle ilgili tartışmalara bolca yer verildiği görülmüştür. Öte yandan hem ismin ve hem de fiilin önüne gelmesi nedeniyle ikisinden birine özgü olma şartını sağlamadığı ve bu nedenle amel etmemesi gerektiği halde amel eden ya da sadece fiile veya sadece isme özgü olduğu ve bu nedenle amel etmesi gerektiği halde amel etmeyen kelime türleri ile ilgili gerekçe arayışlarına da şahit olunmuştur. Aslın dışında kalan bu tür kullanımları, aslın dişına çıktığı halde kabul edilebilir kılan gerekçeler arasında karşılaşılan en dikkat çekici kavramın benzerlik olgusu olduğu tespit edilmiştir. Bu çalışmaya bağlı olarak aynı minvalde ele alınmasının faydalı olacağı düşünülen bir diğer olgunun da benzerlik (şebeh) olgusu olduğu belirtilmelidir.

\footnotetext{
${ }^{58}$ Nâzıru'l-Ceyş, Temhîdu'l-kavâtd, 9: 4317.

${ }^{59}$ Cevcerî, Şerhu Şüzûri'z-zeheb, 1: 394, 395; Ezherî, Şerhu't-Tasrîh ale't-Tavzîh, 1: 338.

${ }^{60}$ Nâzıru'1-Ceyş, Temhîdu'l-kavâıd, 8: 4153, 4154; Cevcerî, Şerhu Şüzûri'z-zeheb, 2: 522; Ezherî, Şerhu't-Tasrîh ale't-Tavzîh, 2 : 370; Sabbân, Hâşiyetu's-Sabbân, 3: 426; Mustafa Galâyînî, Câmiu'd-dürûsi'l-arabiyye, nşr. 'Abdulmün'ım Hafâce (Beyrut: Mektebetu'l-asriyye, 1994), 2: 173.

${ }^{61}$ Sîbeveyh, el-Kitâb, 3: 16.
}

|202|

Hitit Üniversitesi İlahiyat Fakültesi Dergisi, 2019/1, Cilt: 18, Sayı: 35 


\section{KAYNAKÇA}

'Amâyire, Halil Ahmed. el-Âmilu'n-nahvî beyne mueyyidîhi ve mu'arizîhi ve devruhu fî tahlîli'llugavî. B.y.: y.y., 1985.

'Ukberî, Ebu'l-Bekâ Muhibbuddîn 'Abdullah b. Hüseyin. el-Lübâb fî ileli'l-binâi ve'l-i'rab. Nşr. Gâzî Muhtâr Tuleymât - 'Abdülilâh Nebhân. 2 Cilt. Beyrut-Dımaşk: Dâru'l-fikr elmuâsır-Dâru'l-fikr, 1995.

'Ukberî, Ebu'l-Bekâ Muhibbuddîn 'Abdullah b. Hüseyin. et-Tebyîn an mezâhibi'n-naĥtviyyine'lBaśriyyîn ve'l-Kûfiyyîn. Nşr. 'Abdurrahman b. Süleyman el-Useymin. Beyrut: Dâru'lgarb el-İslâmî, 1976.

Cevcerî, Şemsuddîn Muhammed b. Muhammed 'Abdulmün'1m. Şerhu Şüzûri'z-zeheb. Nşr. Nevvâf Cezâ el-Hârisî. 2 Cilt. Medine: Câmi’atu'l-İslâmiyye, 2004.

Dayf, Şevki. el-Medârisu'n-nahviyye. Kahire: Dâru'l-ma'ârif, 1968.

Demâmînî, Muhammed Bedruddîn b. Ebîbekr b. Ömer. Ta'lîku'l-ferâid 'alâ Teshîli'l-fevâid. Nşr. Muhammed b. 'Abdurrahman b. Muhammed el-Müfdî. 4 Cilt. 1983.

Endelûsî, Ebû Hayyân. et-Tezyîl ve't-tekmîl fì şerhi Kitâbi't-Teshîl. Nşr. Hasan Hindâvî. 13 Cilt. Riyâd: Dâru Künûzi İşbiliyâ, 2013.

Ezherî, Halid b. 'Abdullah. Şerhu't-tasrîh ale't-tavzîh. Nşr. Muhammed Bâsıl 'Uyûnu's-Sûd. 3 Cilt. Beyrut: Dâru'l-kütübi'l-'1lmiyye, 2000.

Galâyînî, Mustafa. Câmiu'd-dürûsi'l-'arabiyye. Nşr. 'Abdulmün'ım Hafâce. 3 Cilt. Beyrut: Mektebetu'l-'asriyye, 1994.

Hasan, 'Abbâs. en-Nahvu'l-vâfí. 4 Cilt. Kahire: Dâru'l-maârif bi Misra, ts.

İbn 'Akîl, Ebû Muhammed Bahâüddîn 'Abdullah. Şerhu İbn-i 'Akîl. Nşr. Muhammed Muhyiddin 'Abdulhamîd. 4 Cilt. Kahire: Dâru't-türas, 1980.

İbn Cinnî, Ebu'l-Feth 'Osman. el-Hasâis. Nşr. Muhammed Ali Neccâr. 3 Cilt. Kahire: Mektebetu'l-'1lmiyye, 1952.

İbn Cinnî, Ebu'l-Feth ‘Osman. Sirr'u sınâti'l-i'râb. Nşr. Hasan Hindâvî. 2 Cilt. Dımaşk: Dâru'lkalem, 1993.

İbn Hamza, Mustafa. Nazariyyetu'l-'âmil fi'n-nahvi'l-'Arabî-Dirâse te'sîliyye ve terkîbiyye. B.y.: y.y., 2004.

İbn Hişâm, Ebû Muhammed 'Abdullah Cemâlüddîn. Evdahu'l-mesâlik ilâ Elfiyyeti İbn Mâlik. Nşr. Muhammed Muyhiddîn 'Abdülhamid. 4 Cilt. Beyrut: Mektebetu'l-'asriyye, ts.

İbn Hişâm, Ebû Muhammed 'Abdullah Cemâlüddîn. Muğni'l-lebîb 'an kutubi'l-e'ârib. Nşr. 'Abdüllatif Muhammed el-Hatîb. 7 Cilt. Kuveyt: Silsiletu't-turâsiyye, 2000.

İbn Hişâm, Ebû Muhammed 'Abdullah Cemâlüddîn. Tahlîsu's-şevâhid ve telhîsu'l-fevâid. Nşr. 'Abbâs Mustafa es-Sâlihî. Beyrut: Dâru'l-kitâbi'l-'Arabî, 1986.

İbn Kayyim el-Cevziyye, Ebû 'Abdillâh Şemsüddîn Muhammed b. Ebî Bekr b. Eyyûb İbn Kayyim. İrşâdü's-sâlik ilâ halli elfiyeti İbn Mâlik. Nşr. Muhammed b. 'Ivad b. Muhammed es-Sehlî. Riyâd: Mektebetu edvâi's-selef, 2002.

İbn Mâlik, Cemâlüddîn Ebû 'Abdullah Muhammed b. 'Abdullah. Şerhu'l-kâfiyeti'ş-şâfiye. Nşr. 'Abdülmün'ım Ahmed Hüreydî. 5 Cilt. Riyâd: Dâru'l-me' mûn li't-turâs, 1982. 
İbn Mâlik, Cemâlüddîn Ebû 'Abdullah Muhammed b. 'Abdullah. Şerhu't-teshîl li İbn Mâlik. Nşr. 'Abdurrahman Seyyid - Muhammed Bedevî el-Mahtûn. 4 Cilt. Kahire: Hicr li't-tıbâa ve'neşr, 1990.

İbn Manzûr, Ebu'l-Fadl Cemâlüddîn Muhammed b. Mukerrem. Lisânu'l-'Arab. 15 Cilt. Beyrut: Dâru sâdir, 1414.

İbn Serrâc, Ebû Bekr Muhammed b. Sehl. el-Usûl fi'n-nahv. Nşr. 'Abdülhüseyin el-Fetlî. 4 Cilt. Beyrut: Müessesetu'r-risâle, 1996.

İbn Ya'îş, Ebu'l-Bekâ Ya'îş b. Ali. Şerhu'l-Mufassal li'z-Zemahşerî. Nşr. Emîl Bedi' Yakub. 6 Cilt. Beyrut: Dâru'l-kütübi'l-'1lmiyye, 2001.

İbnü'l-Enbârî, Ebu'l-Berekât 'Abdurrahman. el-İnsâf fì mesâili'l-hılâf beyne'l-basriyyîn ve'l-kûfiyyîn. 2 Cilt. Beyrut: Mektebetu'l-'asriyye, 2007.

İbnü'1-Haşşâb, Ebû Muhammed 'Abdullāh b. Ahmed b. Ahmed b. Ahmed. el-Mürtecel fî şerhi'lCümel. Nşr. Ali Haydar. Dımaşk, 1972.

İbnü'n-Nâzım, Ebû 'Abdillâh Bedrüddîn Muhammed b. Muhammed b. 'Abdillâh b. Mâlik. Şerhu İbn Nâzım alâ Elfiyeti İbn Mâlik. Nşr. Muhammed Bâsil 'Uyûn es-Sûd. Beyrut: Dâru'l-kütübi'l-'1lmiyye, 2000.

İsfahanî, Rağıb. Müfredât'u elfâzi'l-Kur'ân. Nşr. Safvân Adnân Dâvûdî. Dımaşk \& Beyrut: Dâru'lkalem \& Dâru'ş-Şâmiye, 2009.

Kefevî, Ebu'l-Beka Eyyüb bin Musa el-. el-Külliyyât mu'cem fi'l-mustalahât ve'l-furûki'l-lugaviyye. Nşr. Adnan Derviş, Muhammed el-Mısrî. Beyrut: Müessesetu'r-risâle, 1998.

Mustafa, İbrahim. İhyâu'n-nahv. Kahire: Matbaatu lecneti't-telif ve'n-neşr, 1992.

Müberred, Ebu'l-Hasan Muhammed b. Yezîd. el-Muktedab. Nşr. Muhammed 'Abdulhâlik ‘Udayme. 4 Cilt. Kahire, 1994.

Nâzıru'l-Ceyş, Muhammed b. Yusuf b. Ahmed. Temhîdu'l-kavầd bi şerhi Teshîli'l-fevâid. Nşr. 'Ali Ahmed Fahir ve diğerleri. 11 Cilt. Kahire: Dâru's-selam, 2007.

Sabbân, Ebu'l-İrfan Muhammed b. 'Ali. Hâşiyetu's-Sabbân 'alâ Şerhi'l-Üşmûnî 'alâ Elfiyyeti'bni Mâlik E Şerhu'ş-şevâhid li'l'Aynî. Nşr. Tahâ 'Abdurraûf Sa'd. 4 Cilt. Yyy: el-Mektebetu'ttevfîkıyye, ts.

Sâmerrâî, İbrahim. en-Nahvu'l-'Arabî fì muvâceheti'l-'asr. Beyrut: Dâru'l-cîl, 1995.

Sîbeveyh, Ebû Bişr 'Amr b. 'Osman b. Kanber. el-Kitâb. Nşr. 'Abdüsselâm Muhammed Hârun. 5 Cilt. Kahire: Mektebetu'l-hancî, 1988.

Sîrâfî, Hasan b. 'Abdullah b. Merzübânî Ebû Saîd. Şerh'u Kitâb'i Sîbeveyh. Nşr. 'Ali Seyyid 'Ali Ahmed Hasan Mehdelî. Beyrut: Dâru'l-kütübi'l-'1lmiyye, 2008.

Süheylî, Ebu'l-Kâsım 'Abdurrahman b. 'Abdullah. Netâicu'l-fiker fi'n-nahv. Nşr. 'Adil Ahmed 'Abdulmevcud, 'Ali Muhammed Muavvad. Beyrut: Dâru'l-kütübi'l-'1lmiyye, 1992.

Süyûtî, Celâlüddîn. el-ìktirâh fî usûli'n-nahv. Nşr. 'Abdulhakîm 'Atıyye. Dımaşk: Dâru'l-Beyrûtî, 2006.

Süyûtî, Celâlüddîn. Hem'u'l-hevâmi' fî şerhi cem'ı'l-cevâmi'. Nşr. Ahmed Şemsüddîn. 3 Cilt. Beyrut: Dâru'l-kütübi'l-'ilmiyye, 1998.

Şâtıbî, Ebû İshâk İbrahim b. Mûsa. el-Mekâsıdü'ş-şâfiye fi şerhi'l-hulâsati'l-kâfiye. Nşr. 'Ayyâd b. 'Îd es-Sübeytî. 10 Cilt. Mekke: Câmi'atu Ummu'l-kurâ, 2007. 
Tehânevî, Muhammed b. Ali. Mevsûatu keşşâf-ı ıstılâhâti'l-fünûn ve'l-'ulûm. Nşr. Ali Dahrûc. 2 Cilt. Beyrut: Mektebetü Lübnan Nâşirûn, 1996.

Üşmûnî, Ebu'l-Hasen Nûruddîn 'Alî b. Muhammed b. Îsâ b. Yûsuf. Şerhu'l-Üşmûnî 'alâ Elfiyeti'bni Mâlik el-müsemmâ Menhecü's-sâlik ilâ Elfiyyeti'bni Mâlik. Nşr. Muhammed Muhyiddin 'Abdulhamîd. 3 Cilt. Beyrut: Dâru'l-kütübi'l-Arabî, 1955.

Verrâk, Ebu'l-Hasan Muhammed b. 'Abdullah. 'Ilelu'n-nahv. Nşr. Mahmud Câsim Muhammed Dervîş. Riyâd: Mektebetu'r-rüşd, 1999.

Zeccâcî, Ebu'l-Kâsım 'Abdurrahman b. İsmail. Mecâlisu'l-'ulemâ. Nşr. 'Abdüsselâm Muhammed Hârun. Kuveyt: Matbaat'u-Hukûmet'i-Kuveyt, 1984. 
